\title{
The tree that responds: taming the rubber tree
}

\author{
Eduardo Di Deus ${ }^{1}$ \\ - Universidade de Brasília, Faculdade de Educação, Brasília/DF, Brasil
}

\begin{abstract}
The starting point of this article is the assertion, common among tappers (or seringueiros) in plantations in the interior of São Paulo, that it is necessary to tame rubber trees (Hevea brasiliensis) at the beginning of each harvest. They use this phrase to indicate the need to accustom the trees, from the first cuts, to establish an optimal flow of latex. The process of taming the tree is also discussed here based on historical ethnographic materials regarding relationships established with rubber trees in the last decades of the nineteenth and early twentieth centuries, both in the Amazon and in the nascent plantations in Southeast Asia. British naturalists from different colonies came to dispute who "discovered" the fact that the rubber tree possesses a mechanism that they called the "wound response". Based on this diversity of references to the modes of relationship with the peculiar characteristics of the rubber tree, I seek to elucidate, by viewing the genesis articulated between technical and vital rhythms, what it means to affirm that a tree responds or is tamed.
\end{abstract}

Key words: technique; rubber tappers; human-plant relationship. 


\section{A árvore que responde: amansando a seringueira}

\section{Resumo}

Este artigo tem como ponto de partida a afirmação, comum entre sangradores (ou seringueiros) em plantações no interior de São Paulo, de que é preciso amansar as seringueiras (Hevea brasiliensis) no início de cada safra. Com isso eles indicam a necessidade de acostuma-las, nos primeiros cortes, para que estabeleçam um fluxo ótimo de látex. O processo de amansar a árvore será aqui discutido também a partir de materiais etnográficos históricos a respeito de relações estabelecidas com as seringueiras nas últimas décadas do século XIX e início do XX, tanto na Amazônia quanto nas nascentes plantações no sudeste asiático. Naturalistas britânicos de diferentes colônias chegaram a disputar quem teria "descoberto" o fato de a seringueira possuir um mecanismo por eles chamado de "resposta à ferida". A partir desta diversidade de referências aos modos de relação com características peculiares da seringueira, busca-se entender, com um olhar para a gênese articulada entre ritmos técnicos e vitais, o que significa dizer que uma árvore responde ou é amansada.

Palavras-chave: técnica; sangradores de seringueira; relação humano-vegetal. 


\title{
The tree that responds: taming the rubber tree
}

\author{
Eduardo Di Deus
}

In the initial contacts established in ethnographic research with the rubber tappers (or seringueiros), workers who extract latex from the rubber tree (Hevea brasiliensis) in the plantations under expansion in the interior of the state of São Paulo스 Brazil, a term used by them drew my attention. They said that it was necessary to amansar [lit. tame] the rubber tree. By this they meant that at the beginning of each harvest, the first tappings are made with the purpose of accustoming the trees to increase and stabilise the amount of liquid that runs from the bark excisions. The curious thing about this reference to a relationship with a tree is that the word tame, the formal definition of which approximates calm, appease or settle, has a strong connection with animal relationships. Some Portuguese language dictionaries include expressions like "to make something meek or docile", in reference to a "beast", among the first few meanings of the term. Taming the rubber tree, in this sense, seems to refer to stabilising the relationship. I followed this throughout the research, while always attentive to this process, referred to by some as dar frequência [lit. establish frequency]. Interest in these facts gained momentum when I came across numerous similar references in historical material concerning the diaspora of this native Amazon tree throughout the tropical world, including a controversy among British naturalists in the eastern colonies in the early decades of rubber tree use outside the Americas over disputes regarding the discovery of a certain pattern of wound response, during the transition from the nineteenth to the twentieth centuries. While contemporary São Paulo rubber tappers (and agronomists) talk about taming the tree, a little over a century ago, British colonial naturalists said that rubber trees presented a peculiar way of responding to human actions, unlike other rubber producing plants. It would not be an exaggeration to say that this characteristic of the rubber tree constitutes an important affordance (Gibson 1979) wherever someone has engaged in the extraction of its latex.

In the doctoral research in anthropology that originates these reflections (Di Deus 2017), the focus on techniques and abilities emerges as a comprehensive starting point of processes at different scales, both ethnographically and historically. In this research, I began a historical discussion concerning the way that humans relate to these trees, proposing an interpretation of the long-term technical transformations (Sautchuk 2017) in the forms of extraction. I sought to recover the earliest records on ways of extracting rubber from South American rubber-producing species, through developments at the height of the rubber economy, transferral of the rubber tree to Asia, and the repercussions of Asian crop development on the forms of extracting in the Amazon. To a certain extent, I followed the technical relationships that made the rubber tree viable in different historical moments, regions and relationship systems, considering how the forms of latex extraction, their dynamics, are fundamental to understanding this history. I developed an approach focused on the transference of technology in the plant world that seeks to address the developments of "technical systems" (Gille 1978), understanding that the movement of plants and animals is accompanied by movements in the forms of relationships with them. In this sense, I mobilised the anthropology and history of the techniques to consider

\footnotetext{
1 In the Amazon region, the term used to refer to workers who extract latex from the rubber tree is seringueiro, in reference to the Portuguese name of the tree, seringueira or seringa, whereas on plantations in the interior of São Paulo, the term for those who perform this activity is either seringueiro or sangrador [lit. bleeder]. The latter term emphasises the activity performed rather than the plant. In this text, we will use only the current term in the English language, rubber tapper.
} 
the skilful and effective meeting of workers with the plant world from a perspective of the transformations of technical systems, oriented by the different ways in which the different rubber extractors were related to the trees' characteristics'.

This article is an attempt to correlate the historical and ethnographic materials of this research. The skilful relationship of the rubber tappers (or seringueiros) with the trees is of fundamental importance in the agricultural sector called rubber culture, situated in the region known as the western plateau, in the interior of São Paulo. The core of this complex human-plant relationship is the ability to make cuts deep enough to open as many latex conducting vessels as possible, without harming the inner layers of the tree, the wood or, as the locals say, madeira [lit. timber]. All this at a good ritmo [lit. pace], with intense speed. In this article I try to elucidate how certain rhythms of this very special plant make us reflect on the human-plant relationship as a dialogue, based on actions and reactions. The article is founded on the growing field of anthropological studies on the techniques associated with the plant world, presenting, as is characteristic of the core field authors (Sigaut 1975; Haudricourt 1987), a historical view on certain relationships between humans and plants. Thus, converging with that proposed in a recent and very rich work on the history of the rubber industry, herein I defend the importance of strengthening the historical gaze in anthropology beyond a vision of "contextual background" (Nugent 2018: 17). Looking at the emergence and connection of technical systems in a plan of global diaspora of a plant species, in this article, I seek to draw attention to how the anthropology of forms of relationships with the plant world can benefit from a historical view of technical transformations in the relationships with certain species.

\section{Who "discovered" that the trees respond?}

In the first decade of the twentieth century, rubber tree cultivation began to spread in the form of linear plantations in Southeast Asia, following the efforts of the British Empire to overcome the Amazonian hegemony in the production of natural rubber, a product in demand by numerous industrial branches. It was the onset of the era of tires and automobiles. Less than three decades earlier, this native tree had been taken by British to its tropical colonies in the East (Dean 1987; Weinstein 1983). However, it was only after the crisis that the growth of coffee in the State of São Paulo caused in coffee-growing in the Malay peninsula in the 189os that the idea of planting a rubber-producing tree was seen as feasible for Asian producers. The historiography of the rubber tree attributes Henry N. Ridley, a British naturalist based in Singapore, with the deed of having spread this culture in the region. It is said that 'Mad Ridley' walked with seeds in his pockets, promoting its advantages. Yet Ridley was praised, mainly for being considered the "inventor" of modern rubber tapping, establishing and disseminating a way of extracting that enabled linear plantations, according to agronomic precepts, a new mode of existence for this plant (Cook 1928; Fairchild 1928a and 1928b; Dean 1987).

\footnotetext{
2 The research from which this work originates is based primarily on the ethnography of the labour practices of the rubber tappers, rubber plantation workers in northwest São Paulo. It consisted of the observation and description of the work of the tappers in their routines, with the tasks of tapping as its starting point. However, I went beyond the indirect observation of their work. I immersed myself, becoming an apprentice of the craft of tapping, a resource that, according to Wacqüant (2002) and Sautchuk \& Sautchuk (2014), extends the potential of accessing the reflections of practitioners on their activities. Using this field strategy, I initially participated as a student of training courses regularly provided in the interior of São Paulo. Subsequently, I settled in different farms as a neophyte at work and engaged in the tasks of tapping under the supervision of experienced tappers. In addition, in order to develop the historical aspects of this study, I conducted research on archives and in libraries important to rubber tree cultivation, among which I should highlight: the IBAMA library in Brasilia, where the collection of the extinct Superintendência da Borracha (SUDHEVEA) [Superintendence of Rubber]; the library and the archive of the Agronomic Institute of Campinas (IAC); the library of the Botanical Garden of Rio de Janeiro; the National Library of Rio de Janeiro; two libraries of the Centre de coopération internationale en recherche agronomique pour le développement (CIRAD) in Montpellier and in the region of Paris, France; and the historical archives of the Royal Botanical Gardens, Kew, England.
} 
This new mode of existence provided the emergence of a new mode in the technical relationship with the plant. In this sense, it would be no exaggeration to say that the transformation in the mode of latex extraction was fundamental to the consolidation of rubber plantations. In the nineteenth-century Amazon, the tree was exploited along rubber trails, at a density of one or two individual trees per hectare of native forest. In Asia, it was planted in large concentrations of 400-50o trees per hectare. In the Amazon, at that time, hatchets were used to make incisions in the tree bark and the latex was collected with small bowls. After a period of extensive experimentation with various tools and procedures, in several British, Dutch and French colonies, Ridley was attributed with having discovered the knife extraction method. The essence of his "discovery" was replacing the incisions made in the bark using the Amazonian hatchet, by continuous excisions of the bark with knives. Careful excisions minimised injuries to the woody tissue of the trees, unavoidable with hatchet blows, extending the useful life of the trees now planted in line.

However, it was not a direct path, fruit of the genius of an "inventor" of modern tapping, H. N. Ridley, as seems possible to infer from the narrative of the leading historian on rubber tree cultivation:

By the end of the decade of the 189os, the combined, even though uncoordinated, efforts of Ridley and his collaborators, botanists at Peradeniya, and numerous planters and tappers had resolved most of the uncertainties surrounding Hevea brasiliensis [...] Tapping methods were much improved over those employed in the Amazon. To take the place of the small hatchet, knives were designed that excised thin slices of the bark. Repeated excision of the same portion of bark was found to increase, rather than reduce, the flow of latex (Dean 1987: 30).

As Dean himself reports, the rubber tree had a difficult start in those lands because there was not much confidence that cultivation could be viable. Local species such as Ficus elastica, or even other South American rubber-producing species, such as maniçoba or Ceará rubber (Manihot glaziovii) and caucho (Castilla elastica) were preferred. Tapping with knives was disseminated throughout the world where rubber trees were planted, and became the most used method, including in the non-Amazonian South American plantations, for example, where it is the rule in contemporary plantations in the State of São Paulo. In some places in Asia, a type of gouge is also used, but the way in which the panel of the tree was handled is very similar to the way it is done with the tapping knife.

However, to arrive at the Asian tapping system stabilised by this type of knife, a series of attempts and experiments were made with different tools and methods of extraction. Much more than a simple, straightforward passage from the use of small axes to the simple, effective jebong knives, this period was marked by a large profusion of tool models, stimulated not only by the creative drive of the first cultivators and agents of the botanical gardens, but also by contests held by the colonial administration (Willis 1906: 121-126). 
Figure 1 - The diversity of tools used to extract latex
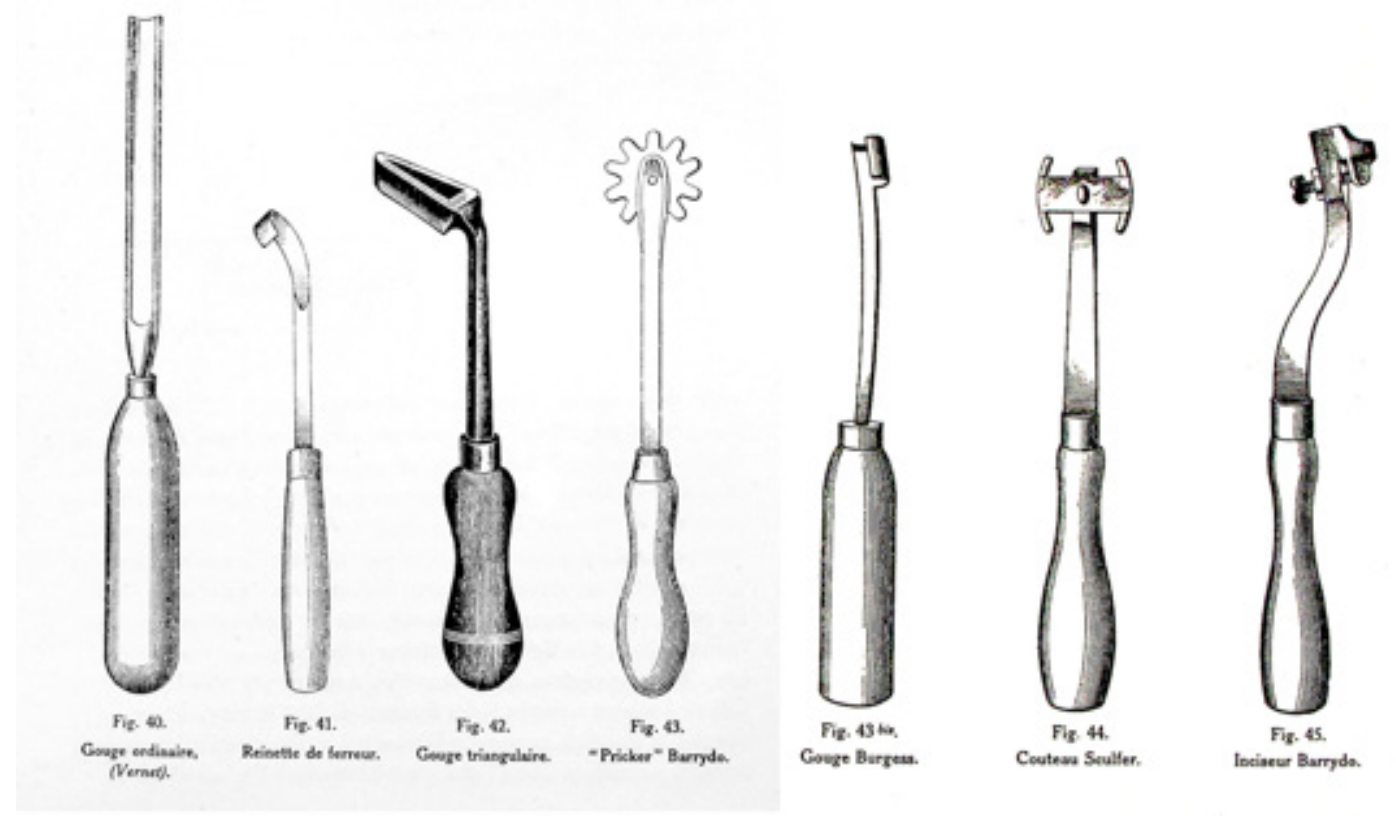

(Labroy \& Cayla 1913: 96-97)

A key differentiation here, a subject of debate at the time, is between bark incision methods and bark excision methods. The Amazon hatchet used a mode of action based on localised incisions. The knives and gouges that came to be tested in Asia were based on the excision of parts of the bark. Even so, incision methods were tested in Asia, among which extraction with rotative pricking tools seem to have acquired approval for a period of time (Willis 1906: 125-6). Until the 1970s and 1980s, puncture tapping methods, which consist of puncture incisions, continued to be tested in different parts of the world.

During this transition, removing or not removing parts of the bark seems to have been less important than control of the tool in relation to the tree. Passing from the hatchet to the tapping knives provided greater control of the action on the bark. According to Leroi-Gourhan's discussion of "elementary means of action on matter" (1971 [1943]: 43-64), this was a transition from a perpendicularly thrown percussion [lit. percussive blow or strike] using the hatchet, to an oblique supported percussion, using the tapping knife. The author thus compares:

The oblique percussion is precise and its results limited, the perpendicular percussion is violent and unusable in a precise task. The supported oblique percussion corresponds to the maximum of softness and control of the tool, the perpendicular percussion launched with the maximum of force and with the relative absence of measurement of the results (1971: 55)

Thus, the adoption of the tapping knives corresponded to a significant gain in controlling the depth of the cut, a fundamental feature to avoid injury to the woody tissue, prolonging the productive life of the trees. Not by chance, this tool would spread widely ${ }^{4}$. This diffusion, however, did not take place without intense debate.

\footnotetext{
3 The original: "La percussion oblique est précise et ses résultats limités, la percussion perpendiculaire est violent et peu utilisable dans un travail précis, la percussion oblique posée correspond au maximum de douceur et de contrôle de l'outil, la percussion perpendiculaire lancée au maximum de force et à l'absence relative de mesure dans les résultats".

4 It is important to take into account Sigaut's (2011: 106-107) reflection on Leroi-Gourhan's classification of the means of action on matter, in the sense that the very idea of percussion is not the most adequate to define actions like supported strikes, percussions posées, which are closer to a form of pressure. On the other hand, even though the amplitude of the concept of a percussion is questionable, I believe that the typology still serves its purpose when analysing the differences between modes of action found in practical situations.
} 
Carl de la Rue, an official with the US Department of Agriculture, published a study in the 1920 on the rubber industry in the Amazon, citing the controversy between incision (hatchet and other tools) versus excision (gouge/knife) at the onset of the Asian plantations (La Rue 1926: 15-6). Some believed, the author says, that the new Asian excision techniques would be harmful to trees. One of these was the man who introduced Hevea to Asia, Wickham, who until the first decade of the twentieth century sought to establish himself as a reference for rubber culture, having published a practical manual of its cultivation in London (Wickham 1908: 24-28, 37-38). He defended the incision-based methods, even though a modified version, which no longer involved hatchets, rather chisels hammered by a wooden stick ${ }^{5}$, which Leroi-Gourhan would call a supported percussion using a striking tool, a method that provides a little more precision in comparison with the thrown percussion of a hatchet.

Figure 2 - Comparison of the principles of knife and hatchets actions
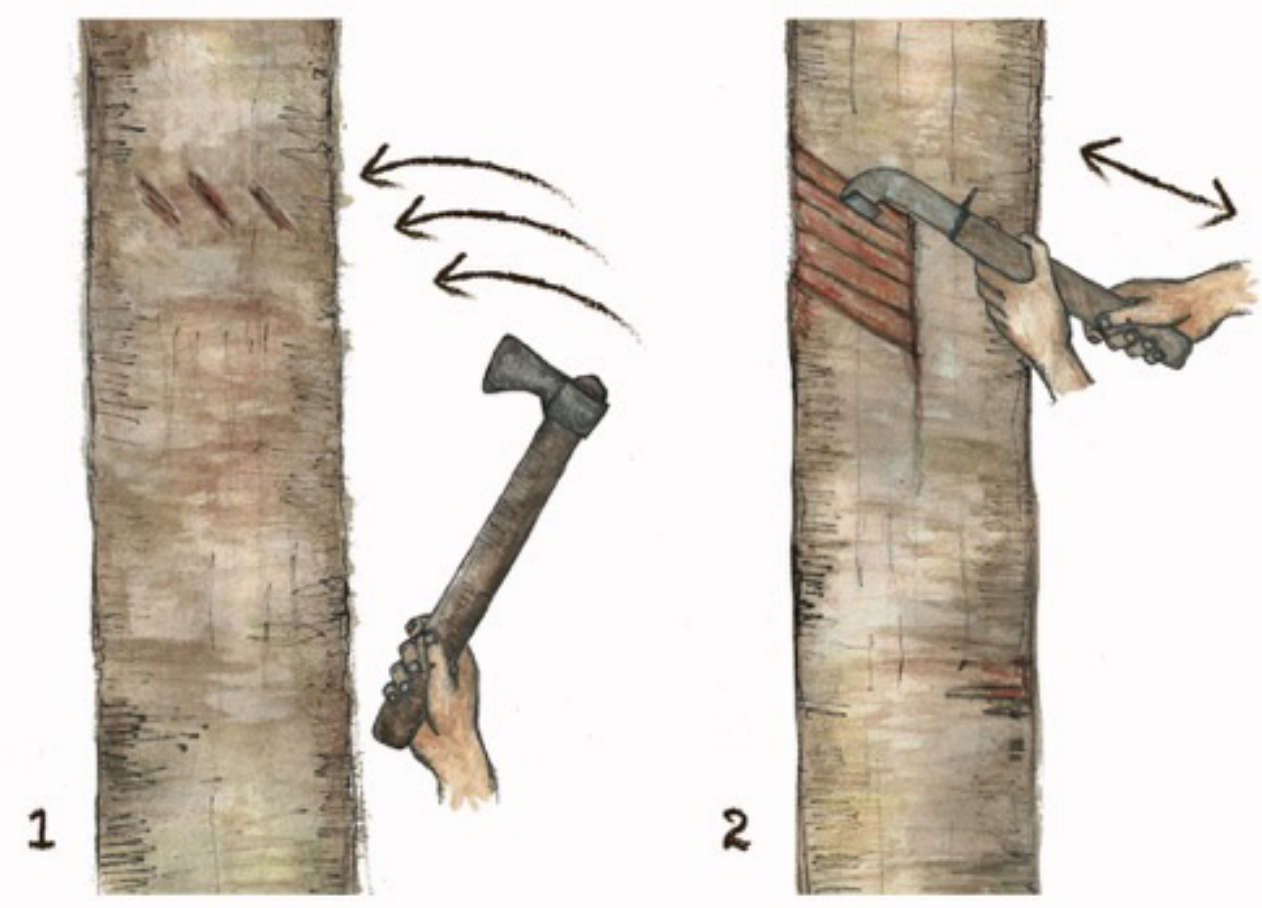

(drawing: Marina Mendes da Rocha)

Wickham criticised the excision methods being tested at the time (spirals, herring-bone and $\mathrm{V}$ cuts), believing that the removal of bark that occurred in these methods consumed the bark very quickly, in addition to increasing the risk of pest attack and diseases. De La Rue defended the opposite, that incisions were always bad for the trees, because the axes or other thrown percussion instruments generated little control with respect to the depth of the cut, making it almost impossible to handle them without producing the almost omnipresent swellings and knots that were ascertained in rubber trees worked and injured this way:

\footnotetext{
5 "The three oblique incised cuts one above the other should be clean-cut with a smart tap made by an ordinary carpenter's (one-inch) chisel held with a firm, straight wrist, to be made by a quick percussion blow with a wooden mallet" (Wickham 1908: 25). The Englishman warned of the need to quickly remove the blade from the cut, so as to avoid injury to the cambium.
} 
If there ever were seringueiros who were careful in using the machadinho the tribe has vanished from the soil - and the waters - of Amazon area! It is hard to imagine what the incisionists thought the ever-present knots and swellings around the base of the tree might be (La Rue 1926: 15-16).

This author goes so far as to suggest that the wounds generated by these techniques even influenced the first botanical descriptions made by the French naturalist François Fresneau in the eighteenth century, who had drawn the trunks of the rubber trees with a type of scale, as if it were as a natural feature, comparing them with some types of palm trees that have this characteristic. Thus, it is possible to imagine that even the "naturalist" descriptions historically dealt with plants grown together with humans, familiarised, managed, in short, in the process of domestication.

Reinforcing the hypothesis that there had been a cumulative process in this transition, Ridley, the inventorhero himself, mentions an old report by Englishman James Collins as an influence on his research in Singapore in the 189os (Ridley 1928: 5). Based on investigations conducted at the Port of London, Collins (1872: 36-37) had compiled state of the art knowledge on rubber-producing plants even before the rubber tree crossed the Atlantic Ocean. He suggested the use of horseshoe-like knives, warning of the need to reduce injuries to the "cambium layer". In addition to Collins, other naturalists, such as Robert Cross (1876) and H. Wickham (1876), sought not only seeds and seedlings in the Amazon, but also investigated a complex of information and techniques on how to make rubber trees produce latex.

The interesting thing is that, even though he was later celebrated as a great hero of rubber culture, while in Singapore, Ridley rivalled his British colleagues of a colony with greater agronomic tradition, Ceylon (now Sri Lanka). A controversy was established between Ridley and the directors of the Botanic Gardens in Ceylon, Willis and Parkin. In 1899, they disclosed the "discovery" of a physiological effect of tapping, which they named "the effect of wounding on the flow of latex", later summarised by the term "wound response"6 (Royal Botanic Gardens 7 , Ceylon: 1899).

They referred to the fact that, unlike other rubber-producing species, such as the South American caucho (Castilla elastica) or the African Funtumia elastica, characteristically the rubber tree does not generate a large volume of latex from the first cut made, it is necessary to perform new taps on subsequent days to obtain a larger volume of latex:

In Circular No. 4 of this Series, January, 1898 , on Rubber Cultivation, it is shown in a series of experiments made by the Director [Willis] on a number of Hevea trees that the second tapping gives a much larger yield of rubber than the first - the numbers indicate just about double the quantity. This is a very remarkable and important fact, and one which hitherto has not been scientifically observed. The natives of the Amazon Valley seem, however, to be aware of it, although no reference is made to it in such a comprehensive work as Seeligmann's "Le Caoutchouc et la Gutta-percha." The Director in conversation with Mr. Gwynne-Vaughan, a botanist who has visited the Amazon Valley, was told that the rubber tappers, when a freshly-tapped tree does not yield a large amount of latex, say that it has not got used to milking yet (RBG, Ceylon 1899: 133; emphasis added).

For the people of Ceylon, therefore, it was a discovery, since it consisted of the first "scientific observation" of a fact that Amazon Indians "seemed" to know. In addition, they said that there was no mention of the fact in works considered references on rubber, there were only reports of the same by Europeans who had visited the region of origin of the rubber tree.

$6 \quad$ Labroy and Cayla (1913: 26-7) proposed translating the term as "resposta à ferida" [lit. response to the wound]. Wound here is understood not as a harmful injury that generates calluses and other inconveniences to the bark, but merely the idea of opening up part of the bark so that the latex flows out. The agronomist Marcos Bernardes (1995: 20-21) uses the Portuguese term "resposta à sangria" [lit. response to the tapping] .

7 Hereafter RBG. 
Ridley's response to this "discovery" is revealing regarding the complex process of the comings and goings of the rubber tree and a certain hierarchisation of technical knowledge on how to relate to this plant. Initially, Ridley (1910: 201-3) minimised the importance of the announcement of the Ceylon researchers, publishing in a local newsletter at the time of the controversy, saying that as soon as he arrived in Singapore and began his experiments at the end of the 188os, ten years before competitors stepped up their research, he himself had "discovered" this physiological effect, a procedure he named "calling the rubber". Moreover, Ridley said that this effect was fairly banal, observable to anyone who had performed successive tappings on rubber trees. Finally, he stated that he had been visited by seringueiros from the Amazon ${ }^{8}$, who confirmed that they already knew of this effect, and for this reason he had not recorded this fact as an important discovery. Ridley thus criticises some articles published by Willis and Parkin of Ceylon in the journals India Rubber Journal and India Rubber World9:

In these papers the incompleteness and inaccuracy lies in the account of the so-called re-discovery of woundresponse, which it was first claimed was an original discovery by Messrs. Willis and Parkin, in 189g, but later as a re-discovery of a phenomenon known to the Amazons seringueiros and some other points. The discovery that the second and later tappings of a rubber tree produce a greater flow of latex than the first is one that no one can possibly overlook who taps a tree consecutively for a few days running and notes the result [...] Needless to state we discovered what is now called "wound response" shortly after we commenced tapping in 1889, but from some Brazilian seringueiros who visited the Gardens later, I found that it was well-known to them, so did not record it as an important discovery on my part (Ridley 1910: 201-203).

Sources that indicate the wide diffusion of knowledge concerning this physiological dynamic of the rubber tree are abundant. Lock, who worked at the Henarathgoda Botanical Garden in Ceylon, stated that the wound response was long known to "collectors of wild rubber" (1913: 60). In addition, Lock emphasises that this physiological characteristic is particular to Hevea and to another plant from the same botanical family (euphorbiaceae), maniçoba, compared with other rubber-producing species ${ }^{10}$. Concerning the variation in exudation in the same tree between morning and afternoon, Labroy and Cayla say that this was

a fact well known to all rubber tappers; it is also more abundant after a certain number of tappings: and is a phenomenon particular to Hevea, the always verified, but as yet unexplained, resposta áferida', the 'wound response' of the English (Labroy and Cayla 1913: 26-27) $)^{11}$.

A Frenchman named Cibot (1903: 4), who visited Bolivian rubber plantations, mentioned in a report something he called the "phenomenon of habituation" (phénomène de l'accoutumance). This was a fact reported by extractors from the Beni River, according to which the amount of latex in the first three or four taps is very small, and it is necessary to accustom or habituate the tree. Colonel Labre (1873: 9), a rubber worker who founded the town of Labrea, State of Amazonas, on the Purus River, had already mentioned in 1873 the need to "prepare the rubber tree" with initial low production cuts.

\footnotetext{
8 In one of his writings, Ridley cites a visit by the seringueiros to the Singapore Botanic Gardens to say that their methods were not efficient: "We had once two professional Seringueiros (rubber makers) from Brazil to try their hand with our rubber, but they made no success of it" (1928: 6).

9 For example, Parkin (1910).

10 "If a tree of Castilloa or Funtumia is tapped, and the wounds are reopened after an interval of a few days, or if the bark is again tapped after a short interval in the neighbourhood of the original cuts, little or no latex is obtained at the second tapping. The bark is milked almost dry at a single operation, and the latex tubes are not completely refilled for several months. The case of Hevea and Manihot, on the other hand, a good yield is again obtained after an interval of only a single day. These facts have long been known to the collectors of wild rubber. The Hevea trees in the forests of Brazil are tapped repeatedly during a single season, whereas in Central America it has frequently been the custom to cut down the Castilloa trees in order that the whole of the available rubber may be obtained at one time" (Lock 1913: 59-6o; emphasis added).

11 The original: “um facto bem conhecido por todos os seringueiros; ella é também mais abundante depois de um certo numero de sangrias: é também um phenomeno particular á Hevea, sempre verificado, mas ainda não explicado, a 'resposta á ferida', o 'wound response' dos ingleses”.
} 
However, when he wrote about the subject at the end of his life in a text on the "evolution of cultivated rubber industry", Ridley removed any mention of the Amazon rubber tappers, claiming only that the people of Ceylon had rediscovered something that he himself had previously discovered.

In this tapping we discovered that it was necessary to open the cuts the day before we required the latex, as the trees did not yield the first day. This we called 'calling the rubber'. I mention this because about 15 years later it was rediscovered by the Ceylon agriculturists and hailed as an important discovery under the name 'wound response' (Ridley 1955 [1930]: 117).

At the beginning of the twentieth century, Ridley was in contention for hegemony in the emerging rubber industry with the people in Ceylon. Unlike Singapore and the Malaysian peninsula, where Ridley says it took ten years to start publishing due to the lack of availability of printers or the resources for printing, Ceylon was considered a benchmark in tropical agriculture, concentrating resources and prestige. So much so that the announcement of the "discovery" of the wound response had great repercussion in the world of the rubber tree. Ridley had the merit of contributing to the enormous diffusion of the rubber tree in the Malaysian peninsula, a region that became the largest rubber producing centre at that time. If it is true that it was not a process of invention by an isolated genius, nor a process that started from scratch, there was a significant transformation based on the experience coordinated by Ridley. It was from this point onwards that continuous layers of bark were removed from the same region of the trunk of the tree, with the help of specific knives, a technique denominated paring.

In fact, what this peculiar characteristic of the rubber tree reveals is that there was a cumulative process of knowledge in the transformations of the mode of rubber extraction. Different from that defended by some versions of the history of rubber trees, reproduced by historians and even by ethnologists studying in Southeast Asia (Wolf \& Wolf 2009 [1936]: 128-129; Dove 2000: 231), knowledge of the mode of the relationship with the species was not "created from scratch" after its arrival in Asia, rather transposition occurred with transformations in the ways of relating to the plant. The relation with this physiological dynamic of the rubber tree is one of the most striking examples of these technical systems in diaspora.

The ethnographic experience in the rubber plantations of the western plateau of the State of São Paulo allows us to interlace some considerations about how this physiological feature, which was already known and used by the old Amazonian seringueiros, is crucial in the routine work of the current São Paulo rubber tappers.

\section{Taming or establishing frequency}

In São Paulo, the rubber tree is tapped for ten or eleven months a year, with a pause during the period that the leaves fall, between August and September. Whenever the rubber harvest begins, usually in September, it is necessary to tame the tree or panel, as Amazon rubber tappers have known and practiced since at least the nineteenth century. The panel is a region of the bark previously delimited by scraping on which successive tappings are performed. The first cuts are important for the tree to be accustomed to producing a constant gush of latex. The São Paulo tappers call this process taming, while workers who migrated from large plantations in Mato Grosso often speak of dar frequência [lit. establishing frequency]. Frequency is an agronomic jargon that has been incorporated by many workers, making reference to the interval between one tapping and another. It is curious that some agronomists from São Paulo have, in turn, incorporated the term amansar [taming], current among tappers and other agents in the field. An important aspect here is that once tamed, that is, once in frequency, it is important to maintain relatively regular intervals between tappings on the same tree to sustain this physiological effect of exuding a good amount of latex. The stimulation of production is maintained by doing this. The most common system currently used in São Paulo is called D/4, in which a task or lot of 
trees is tapped every four days. A few years ago, the system used on the São Paulo plateau was $\mathrm{D} / 3$ (three lots per tapper, visited every three days $)^{12}$. If the tapping interval is prolonged too much, for reasons like a period of heavy rains, the tree ends up "losing frequency", the stimulation that this rhythm provides is lost and production decreases.

Over decades of dealing with the rubber tree, it was perceived that in addition to tapping at regular intervals until the tree increased and stabilised the latex flow, it was necessary to find the ideal interval between one tapping and another, the ideal frequency. For years, agronomic science has pursued what the "ideal" tapping or exploitation system is for each clone in a given region, intersecting with other factors, such as chemical stimulation, in order to obtain greater productivity (e.g., Silva et al., 2007). Bernardes, one of the agronomists specialising in rubber, has thus proposed:

Wound response, or panel taming, is the reaction of the rubber tree to increasing the production of latex after successive tappings. When a tree is tapped for the first time, or after a long cessation of tapping, the latex flowing from the laticiferous vessels is viscous and has a high rubber content, and its flow is short in duration. Subsequent tapping at regular intervals results in an increase in production due to the prolongation of the flow period of a more dilute latex. The tapping interval that provokes this type of response varies from one to several days, and with larger intervals the effect decreases (Bernardes 1995: 20; emphasis added).

It is interesting that in his thesis, Bernardes uses both a derivation of the term coined by the Ceylon researchers "resposta à sangria" (the translation for wound response), and the current term in the interior of São Paulo, amansar o painel [lit. tame the panel] (or the tree). This phenomenon reveals a central fact in rubber culture and in so many other types of relationships with the plant world. The tapper acts on the plant, but not only to excise its components. It concerns a process of action and reaction, involving rhythms and, what is evident here, the responses of the plants.

In addition, it indicates the fact that it is necessary to maintain regularity in the interval of days between cuts (frequency), imposing on the rubber tree a certain discipline for those who work with it. It is necessary to tame and maintain discipline, frequency. It is known that, from the physiological point of view, this interval revolves around two to five days, or up to seven days, and an interval of longer than a week in tapping already decreases the flow. For most clones and in most regions, the frequency considered ideal for generating the highest rubber production is $\mathrm{D} / 3$ or $\mathrm{D} / 4$. However, other factors are taken into account, such as the relationship with what is defined as labour. While in São Paulo, the ideal working frequency is currently $\mathrm{D} / 4$, in other regions where rubber culture has expanded to on somewhat different sociotechnical bases, the frequency used has been $\mathrm{D} / 5$ or even up to the limit, $\mathrm{D} / 6$ or D/7. In regions of the State of Goiás, for example, where there are farms with larger plantations than in São Paulo and where tappers are paid wages - different from the sharecropping system, which is the most common in São Paulo -, the decrease in productivity per tree due to the reduction in frequency is compensated by lower costs for tappers' wages, a fact that makes it an attractive choice for employers in this region. As it turns out, the choices of so-called systems of exploitation involve a tangle of correlated factors of different orders (Di Deus 2017).

It is important to understand how to tame the tree (or establish frequency). Whenever an area of rubber trees has not been tapped for some time, this process must be carried out. The first step to this is quebrar a casca [lit. breaking the bark], according to tappers from São Paulo, or to avivar a sangria [lit. reviving the flow],

12 When rubber culture began in this region, according to reports, the most common system was $\mathrm{D} / 2$. A tapper from São Paulo who has been working for more than twenty years with the same boss informed me that he had a tabela [chart/schedule] from $\mathrm{D} / 2$ to $\mathrm{D} / 4$. $\mathrm{D} / 2 \mathrm{produces}$ a lot, but it causes a lot of panel drying, when the tree stops producing latex. Tabela is a term used by São Paulo tappers that is situated between the lot (territory) and the frequency (interval). The tabela is the division of tarefas [tasks] (as some tappers call the lot). I have heard tappers using the term tabela as a synonym for lot, i.e. the territorial division, but also in reference to frequency. 
according to the migrants. This is the first cut after a period long enough for the bark to regenerate and change the flow dynamics of the latex to the panel. Taming or establishing frequency corresponds to the sequence of two or three cuts, until the latex flow increases and stabilises.

This is necessary at least once per crop, after the parada [lit. pause], the time during which the rubber tree is not tapped, which lasts two months on average. Jair, a São Paulo tapper with ample experience, once told me that "the rubber tree is the same as the milk cow, you have to stop for her to rest". This comparison between rubber and cow, latex and milk, and even between the rubber cup lumps and cheese, is widespread, especially among those from São Paulo. Not only because the products have similar physical characteristics (white liquids), but also because of similar physiological processes (when comparing cow and rubber), or even because of the physicochemical transformations of the extracted materials (comparing latex coagulation and cheese curing). In this sentence by Jair, the physiological dynamics are compared, the need for a pause in the extraction process of latex from the rubber tree and in drawing cow's milk. In short, an analogy between their organic rhythms. It is interesting to note that analogies between organic and technical processes between species do not always coincide with the boundaries of biological classification: this is yet another example, in which an animal species is compared with a plant.

This pause usually occurs in the region between the months of August and September, when the most common clones, such as RRIM 600 and PB 235 , lose their leaves and it is necessary to interrupt the tapping. At this time, the tree uses the nutrients, water and proteins contained in the latex to renew its leaves. In parallel, the bark on the panel begins to thicken.

Figure 3 - Cycles of the rubber tree

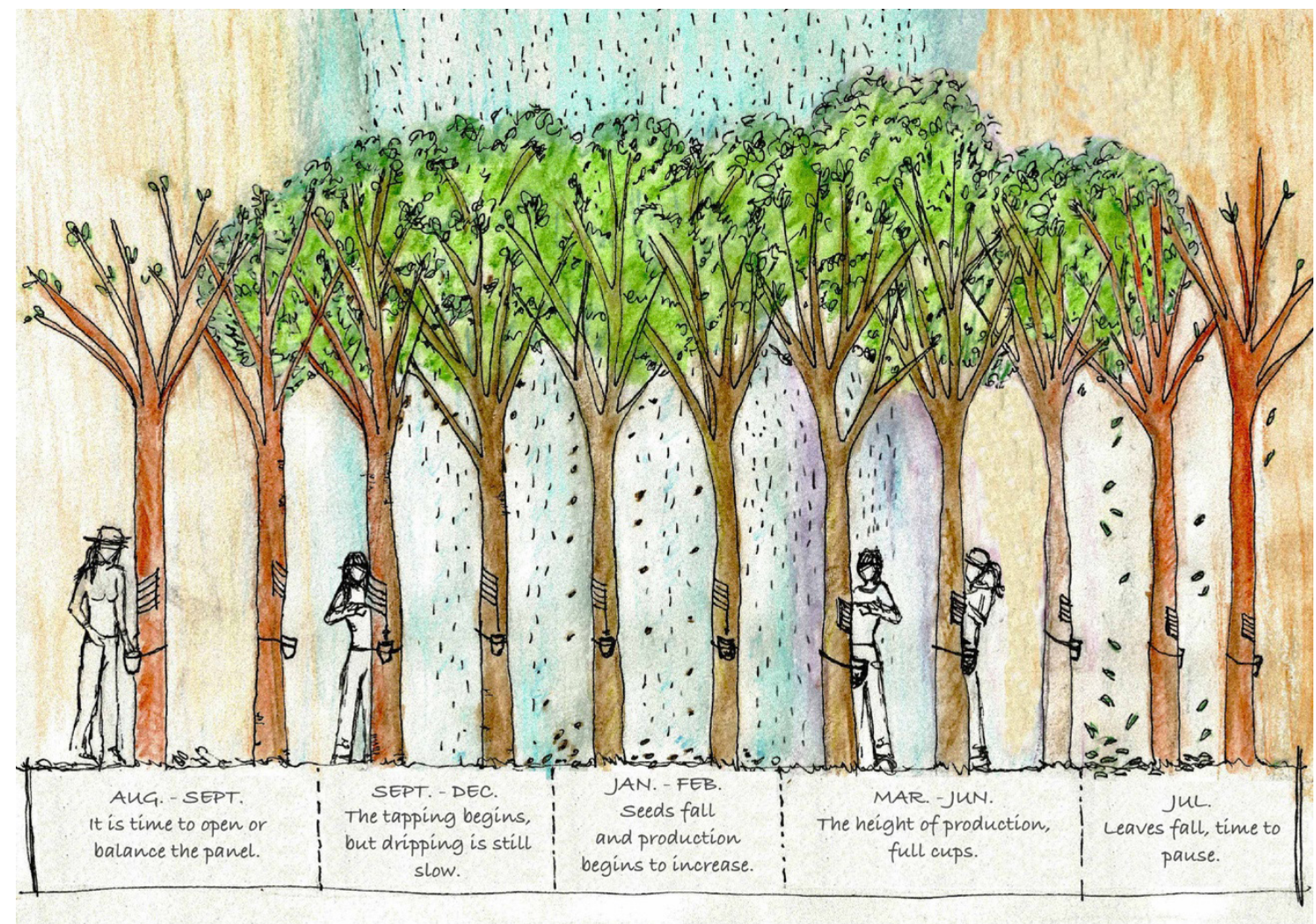

(drawing: Marina Mendes da Rocha) 
The pause usually ends when the leaves are renewed and the rains begin, between September and October's. Then it is time to resume tapping, making the first cuts to tame or establish frequency. The panel can be opened just below the one that was tapped the previous year, or on the other side of the tree. In this latter case, this is known as virada do painel [lit. turning the panel], one of the procedures used to balance the panel. The most common practice today, according to that established in rubber culture manuals and applied in the field by a large portion of producers, is a routine of opening the first three panels on the same side of the tree, where each panel corresponds to half the circumference of the tree, with cuts made in a downward spiral (the so-called half-spiral, described in technical manuals as $S / 2$ ). At the start of the fourth year, turning the panel is carried out for the first time, and the panel is opened on the opposite side to the previous year. From then on, the panel is alternated every year. There are, however, numerous variations in these sequences. Regardless of whether or not the panel is turned, the taming procedure is the same, since the two-month pause is enough that the previous panel no longer remains tamed.

It may be necessary to tame or establish frequency again if an area is not tapped during the harvest, for any number of motives. One of these is the unexpected loss of a tapper in the middle of the harvest, without being able to find a substitute quickly. The turnover of tappers between farms is high, for several reasons. I helped a tapper to revive (break the bark) a lot when the previous tapper and his wife had decided, in the middle of the harvest, to return to their region of origin, outside São Paulo. After more than a month on pause, the cut line had already formed a thicker, deeper bark. The sernambi, which is the small rubber strip that sticks to the last cut line, was already black in colour, while the rubber was a sticky, gooey texture, and difficult to remove. When you make the first cut, you notice the bark is a different colour, such that one of the outermost layers is green and the colour is more intense; a sign, the tapper told me, that these trees were regenerating that area. In these first tappings, it is again necessary to seek the ideal depth of cut, which was lost during the pause. A secondary impact of the pause, which makes this service somewhat uncomfortable, is the accumulation of water in the latex collection cups and the consequent proliferation of mosquitoes.

However, it is not necessary to go one or two months without tapping for the effects to be felt. Even after a pause of just one or two weeks, a lot already begins to show a reduction in its latex flow. On a farm where I accompanied the tapping, I witnessed as one of the lots was left for nine days without tapping because of a succession of rainy days. Even for a beginner like me, it was evident that it was "dripping less" compared with previous taps in the same area. In addition, according to what the tapper told me, "the lot was already losing depth".

Maintaining the frequency relatively stable is therefore one of the ways of stimulating production, or maintaining the tree stimulated. In this sense, a tamed tree is a tree that is stimulated to produce latex. The plant is stimulated to produce by maintaining cuts at relatively regular intervals. Jair once told me, "the agronomist said that I was a sorcerer, because my cups were full while the others had little. It's the way you cut the tree, deep and continuously, to stimulate it to produce".

The other way of achieving stimulation is by application of the chemical stimulant, ethephon, almost always called by the brand name, ethrel, but also by the nickname of groselha (red currant), in reference to the strong pink colour. The use of ethrel is of great importance in the rubber plantation, as it can significantly increase production. Therefore, sharecropper tappers, who earn by production, value its application. However,

13 There is, however, controversy concerning the period of the pause, directly related to the tapper's line of work. In his talks, the agronomist Marcos Bernardes has defended that the pause should be prolonged, such that the tapping is resumed during the period of greatest productivity, in January, and that the harvest should be shorter. He argues that it is economically more interesting to concentrate tapping during the more productive months. With a shorter harvest of about six months, the tapper would lose their specialty and engage in a host of other agricultural activities. Janilson, a tapper who devotes himself exclusively to this profession, disagrees. He argues that this is detrimental to the tapper's line of work, as the worker loses their focus on tapping activities while having to perform numerous other tasks on the farm. On the other hand, Jair, a tapper who has a second job, generally prefers to lengthen the pause so he can build houses in the period of the pause. 
in the history of the rubber tree, chemical stimulation is related to the search for increased production, causing a reduction in tapping frequency and, consequently, in the number of tappers per area. A course book on tapping elaborated by the National Rural Apprenticeship Service in São Paulo (SENAR-SP), contextualises the chemical stimulation as follows:

In order to obtain latex flow (outflow) for a longer period, aimed at increasing the interval between two taps, and thus reducing bark consumption and the quantity of labour, without harming production, the application of chemicals on the tree was adopted (Benesi and Oliveira 2005: 21).

Numerous products have been tested throughout history to stimulate rubber tree production ${ }^{14}$, but etephon has been disseminated as the most adequate and with fewer negative implications ${ }^{15}$. Ethrel releases a vegetable hormone in the plant, ethylene, which is natural and promotes multiple effects: it prolongs the flow of latex by reducing the presence of lutoids, the particles responsible for coagulation; it widens the diameter of the lactiferous vessels, potentiating the flow; and it increases the $\mathrm{pH}$ of latex, favouring the biosynthesis of rubber particles (Bernardes 1992: 6-11). In 1974, its possible inclusion as one of the "new technologies" to be introduced to increase productivity in native rubber plantations (Barros and Aitken 1974: 293) was already being discussed. Bernardes recommended the adoption of ethrel in São Paulo, in the early 199os, but it required extending the interval between taps, since the $\mathrm{D} / 2$ system, the most commonly used at the time, is not the most favourable for stimulation with ethrel (Bernardes 1992).

Ethrel is directly linked to the physiological cycles of rubber trees and to environmental variations, such as rainfall. It is a production stimulant, but it must be applied at favourable times, generating a rhythm that must be followed. The application of ethrel promotes something similar to that which Lemonnier (1992: 21-24), when speaking of "strategic operations", discusses concerning operations that cannot be interrupted once they have been initiated. First of all, in order to apply it, certain conditions must be met, notably a minimum moisture accumulation in the soil (recommendations in manuals vary, but something like at least $100 \mathrm{~mm}$ of accumulated rainfall). In addition, after it is applied, the imperative of maintaining frequency is heightened. Chemically stimulated, the tree must be tapped at the right time, otherwise there may be damage to the tree, such as the panel drying. In this sense, it is can be said that the extra stimulation provided by the chemical agents of ethrel does not superimpose the process of maintaining the tree tame or in frequency, rather it is integrated into this process.

I saw tappers applying ethrel on the panel, with brushes, right above the last cut, but also on the last cut, on the sernambi (a small rubber strip that coagulates at the point of the last cut). The product is carried in small pots diluted in solutions ranging from "three to one" to "five to one", that is, three to five parts water to one part product, since the recommendations vary from one clone to another, and on the orientation that each farm follows. Some employers are more cautious, and prefer lower concentrations and fewer applications per year. The operation of applying ethrel alludes to many relationships, at other levels, as an important mediator of the relationship between tappers and bosses. A good employer and a good rubber estate are evaluated, among other things, by "how often ethrel" is applied over a harvest. Some farmers and agronomists place restrictions

14 "The increase in production with the use of a stimulant for latex flow is not new. Since 1912, when Kamerun filed a British patent to increase latex production through the simple system of scarification of the bark below the cut, several forms of stimulation have been used" (Barros \& Aitken 1974: 293). The authors cite tests with clay, cattle manure, vegetable oils (palm oil, flax and coconut), copper sulphate, 2,4-D and 2,4,5-T growth regulators; the last two induce the plant to produce ethylene, a plant hormone that stimulates growth. In the late 196os, the first tests were performed with etephon, which were widely publicised at a rubber conference in Malaysia in 1970. Bouychou (1962: 35-45), writing from the experience of French colonial plantations in Vietnam and Cambodia and a few years prior to the dissemination of the use of etephon, devotes special attention in his manual on tapping to methods of stimulation, recommending the use of the aforementioned 2,4-D and 2,4,5-T. This chronology of chemical stimulants was reflected in the recommendations of the public agents of rubber culture in the State of São Paulo: Hoelz (1958: 151) recommended 2,4,5-T and 2,4 D; while in the 1970s, a CATI assistance project (1975: 9-10) oversaw the diffusion of the stimulation technique with Ethrel. 
on this stimulant, which is a factor that can even make a tapper turn down an invitation to work on a farm or perhaps contribute to making the decision to move. Perhaps because the limits of its application are disputed its colour is an intense rose, so that the panel is clearly marked after its application.

Ethrel even reveals the contrast between Mato Grosso and São Paulo. An agronomist from São Paulo said this about the product:

If I had a rubber plantation, I wouldn't use ethrel, I'd ban it! It disturbs the plant, dries the vessels. It's the biggest villain on the rubber plantation. I'd do anything at all, fertiliser, but I wouldn't use it. It was in the early 199os that the ethrel fever started. The plant becomes dependent, the more you use it, the more dependent you become, it's a drug. I only talk about it because it's become routine, it's used on $95 \%$ of the rubber plantations. But it has to be used at the right dose and frequency.

This same agronomist told me about the migrant tappers: "they like an ethrel!", defending a position of the use of few applications, different from what he considered excessive among the migrants. But even the São Paulo tappers have developed a predilection for the product, which enables them to make a greater profit.

Ethrel can be considered one more tool in the set of elements that can be worked rhythmically in relation with the rubber tree. It is a potentiator of the physiological processes already managed by the tappers. It is an additional way of stimulating the rubber tree, if we consider that tapping itself, in succession, is just a stimulating element. Thus, this product should be understood in conjunction with the stimulation that the tapping itself provides, when done rhythmically, at the right frequency.

The dimension of maintaining frequency as an important factor in stimulating the tree to produce causes us to reflect on how the action of tapping, an apparently direct and positive action, could simultaneously be an indirect action. This in the terms of Haudricourt (1962), and later taken up by Ferret (2012). Haudricourt compares sheep farming in Europe with the cultivation of yams in Melanesia. He concludes from this that the treatment of nature and the treatment of alterity tend to show similar modes of action in each society. According to Ferret, for Haudricourt:

action is direct when there is a close and/or permanent contact between man and the domesticated being, with the latter acting upon the body of the former; it is indirect in the contrary case, that is, when humans act not upon the domesticated entity, but upon the milieu that surrounds it and influences it. Action is positive when it imposes a certain path upon the domesticated entity according to an a priori schema, and negative when it does no more than bar it from moving in certain ways, judging the result only a posteriori. (Ferret 2012: 115) ${ }^{16}$.

An interesting step to be taken at this time is to draw inspiration from the grammar of these authors to consider actions, not as a strict classification of tapping, but rather to seek inspiration to deepen certain significant traits of the activity under study. The relationship between the tapper and the trees reveals a complex dialogue with the rhythm of the plant itself. In this sense, in what appears to be a single act, tapping seems to comprise two modes of action. In addition to a technical gesture that can apparently be read as a mechanical positive direct action - making cuts in the bark to extract latex - within the management of the very rhythms of the tree's physiology there is a dimension of "making them do" (Ferret 2012), of managing and responding to these rhythms. The tapper taps by performing a direct and positive action on the tree, but by tapping successively, managing and maintaining the frequency so as prevent the tree from losing the ideal latex flow, he

16 From the original: "l'action est directe quand il existe un contact étroit et/ou permanent entre l'homme et l'être domestiqué, celui-là agissant sur le corps même de celui-ci; elle est indirecte dans le cas contraire, lorsque l'homme agit, non sur l'être domestiqué, mais sur le milieu qui l'entoure et influence. L'action est positive quand il lui impose un cheminement selon un schéma a priori, négative quand il se contente de lui barrer certaines voies, ne jugeant du résultat qu'a posteriori”. An English translation of the article is available at: https://www.cairn-int.info/article-E_LHOM_202_o113--toward-an-anthropologyof-action.htm 
makes the tree (continue) to do so. By constructing his practice based on this discipline of relatively constant return, he causes the tree to continue its flow of latex. And by disciplining his frequency of returning to the lots, he disciplines his life with a certain rhythm.

I spoke above of frequency as a level of rhythm in the rubber tree culture, corresponding to the intervals of return to the same lots. However, it should be noted that this ideal frequency is never observed in practice. The tapper sometimes anticipates his return to a lot so he can avoid working on Sunday, on a holiday, or even on a day when he needs to be absent for other motives. It may also be necessary to repor o lote [lit. compensate the lot] after not having tapped on a day, the most common reason being rain. Paradoxically, the period of greatest production potential for a rubber tree plantation is the rainy season, when there is good water availability in the soil for the trees to produce latex. The higher the frequency of rainfall, however, the greater the risk of losing tapping days, since you cannot tap during or immediately after rain. You need to wait until the panel is relatively dry. Otherwise, when the panel is still wet, the latex disperses, it drips outside the cutline and channel, causing large losses.

The following table shows the frequency verified over 16 days in the experience of a tapper, during a period of numerous rains. The marked days represent those on which a tapping was performed. In an ideal scenario, a complete lot per day is tapped, with an interval of four days between each tapping. However, sometimes rain prevents tapping for one or more days in a row, causing most of them to show decreased frequency. Because of the rains, no tapping occurred on 7 of the 16 days. During this period, the interval of days between one tapping and another, which should have been four days, was at least eight. Lot $C$, for example, went ten days without a tapping (between days 2 and 13 ).

Table 1 - Tapping frequency during a rainy period

\begin{tabular}{|c|c|c|c|c|c|c|c|c|c|c|c|c|c|c|c|c|}
\hline Day & 1 & 2 & 3 & 4 & 5 & 6 & 7 & 8 & 9 & 10 & 11 & 12 & 13 & 14 & 15 & 16 \\
\hline Lot A & & & & & & $\checkmark$ & & & & & & & & & $\checkmark$ & \\
\hline Lot B & $\checkmark$ & & & & & & & & & & $\checkmark$ & & & & & $\checkmark$ \\
\hline Lot C & & $\checkmark$ & & & & & & & & & & & $\checkmark$ & & & \\
\hline Lot D & & & $\checkmark$ & & & & & & & & & & & $\checkmark$ & & \\
\hline
\end{tabular}

Some tappers venture to tap before the panel is completely dry. In this situation, Jair told me, "you can't be in a hurry to tap on a wet panel". At this moment, it becomes imperative that the horizontal channel that conducts the latex to the spout and the cup is of good depth, otherwise the latex disperses more easily. There are tappers who reavivam o canal [lit. revive the channel again] regularly, while others do so only on rainy days, when there is a greater risk of losing production. This is because this activity causes a relative increase in working time. Environmental factors, such as solar incidence and ambient temperature, but particularly the wind, actuate to cause the panel to dry faster. Depending on the intensity of the rain, tappers soon give up on that day's work. Others wait until the afternoon when, even though there are higher temperatures that slow the latex flow, they prefer to tap and not lose the frequency. I heard the following phrase from a tapper and an agronomist, "better to tap in the afternoon than not to tap".

I previously noted that the frequency of a four-day interval $(\mathrm{D} / 4)$ was stabilised as ideal for optimum productivity in this region nowadays. However, in the perceptions of tappers, variations are possible and desirable, and some form part of their productive strategies. A tapper who has worked with knives for 20 years and who manages a very productive field of the PB 235 clone, says that at the height of the harvest, 
these trees need to rest for at least five days to allow time to fill the cup from a single cut. He also said that he "does not believe in a table", that is, even though he is aware of the requirement not space out tappings too much, so as not to lose production, he does so more freely without a "table", which is an obligation to sequence the lots as previously programmed.

Indeed, I observed in his routine a malleability in this sequence, sometimes prioritising a tapping after a shorter interval in a more productive area, with the aim of delivering rubber that he had intended for a given day, while allowing a little more time in areas with lower productivity (for example, with young trees, in the first years of tapping, when they still produce less). Having worked with the same employer for about 20 years, he has broad autonomy to act on his own technical choices and said that once "an agronomist came here hands full of papers, but really I do it my way". I observed that "his way" does not neglect the frequency, he tries to replace the days lost due to the rains. He only makes the sequence of each group of trees malleable to the different characteristics of the various lots that he works. Working with lots of younger and older trees, he ends up tapping the new ones less frequently (more days per interval) than the older ones. The frequency is just another example of norms that are managed locally based on the work and life experience of each tapper.

There is, therefore, the imperative to maintain the tapping in the lot planned for that day, even if this tapping is performed the next day, when you try to tap two lots, the lot of that day and the one lost the day before. This is about lot compensation. Rainfall dynamics, therefore, directly interfere with frequency maintenance, so the tapper sometimes does not work on a rainy day in the middle of the week, but feels compelled to tap two lots on a holiday or weekend, assuming there is no rain and it is necessary to anticipate or compensate a lot. This imperative to maintain the frequency and to do so by adapting to rainfall conditions is directly related to the regional preference for forms of hiring that do not determine precise working hours, such as sharecropping.

The use of ethrel, about which I spoke about above, heightens the imperative to pay attention to the rhythms of the rains. According to what I was able to understand from the practice of the tappers, ethrel should preferably be passed two days after a tapping, and the first cut must be made two days after this application. There is no problem if it rains a few hours after passing ethrel, and the more it rains after this the better, as there will be more water available in the soil. However, rainfall a few hours before a tapping is also not good, because the ideal is that the panel is dry. In addition to preventing tapping because the panel is wet, rain can cause the loss of latex that has not yet coagulated in the cups. The hormone acts for about four tappings, but the first one after ethrel application is very productive, and losing it is very prejudicial. If the first cut after applying ethrel is delayed, there can also be serious negative consequences for the trees.

\section{Final considerations}

In short, the tapping of rubber trees is constructed as a working rhythm in relation to certain physiological dynamics of the rubber tree, which are also connected to the environmental dynamics, especially the rains. In this article, I intended to discuss how a certain rhythmic level of the tapper-rubber tree interaction reveals a complex interactive human-plant dynamic. The process of taming the tree and maintaining it tame within a work discipline over days, coupled with environmental dynamics, is very revealing regarding how it is fundamental to understand the minutiae of these fundamental interactions in rural work, which instil rhythms on other scales. As a living being that acts, responds, the rubber tree needs these characteristics to be taken seriously, and even to broaden the understanding of other levels of relationship, such as the relationship between tappers and employers.

We have seen how these characteristics of the rubber tree have marked the history of the different relationships that have been established with these plants since the Amazon of the nineteenth century, through the development of plantations in Southeast Asia in the early twentieth century, and up to the contemporary 
plantations in the interior of São Paulo. I believe that this article strengthens the argument recently raised by Nugent (2018) for preferring the term "rubber industry" to describe what happened in the Amazon in the period known as the "rubber boom". Nugent argues that the term "boom" ends up reinforcing hyper-naturalist ideas about the Amazon, reducing the complexity of the process that exists there, as well as its connections with global networks. Analysing here what I called rubber tree diaspora from a peculiar physiological characteristic of "responding" to certain actions in the tapping process, I believe reinforces the idea that, if it is possible to speak of a long-term "rubber industry", it did not "start from scratch" with the arrival of seeds and the densified planting by European settlers in Southeast Asia, rather there was a connection with the knowledge and practices of the peak of Amazonian rubber analysed by Nugent.

I also believe that this ethnographic and historical view of the transformations in relationships with a cultivated plant species indicates the possibility of answering questions raised in a recent dossier, whose central theme is the possibility of attributing the status of ethnographic subjects to plants (Hartigan Jr., 2019). My answer to the question as to whether it is possible to do "plant ethnography" is positive, indicating a view towards the interactive rhythms between humans and plants. The imperative of taming the rubber tree, together with response dynamic, causes us reflect on the potentiality of a plant anthropology based on the ethnography of relationships established with them, their rhythms in transformations and drifts on a global scale, surpassing a purely metaphorical dimension of the idea that plants have "agency".

Received: September 19, 2018

Approved: July 31, 2019

Translated by: Phil Badiz 


\section{Bibliography}

BARROS, José Cezário Menezes de; AITKEN, William Martin. 1974. "Economicidade e operacionalização do uso do Ethrel como estimulante em seringais nativos no Estado do Amazonas". Arquivos da Superintendência da Borracha - Sudhevea, Centro Nacional de Informações Ambientais - CNIA/IBAMA, Brasília. Mimeo.

BENESI, José Fernando Canuto Benesi; OLIVEIRA, Marco Antônio de. 2005. Sangrador de Seringueira: sangria em seringueira. São Paulo: SENAR.

BERNARDES, Marcos Silveira. 1992. Recomendações para uso de ETHREL PT e ETHREL 2,5 PT como estimulante da produção de látex de seringueira: parecer técnico. Piracicaba: LAG-ESALQ/USP; Rhodia Agro SA.

. 1995. Sistemas de explotação precoce de seringueira cultivar RRIM 600 no planalto ocidental do estado de São

Paulo. PhD thesis in Agronomy - Escola Superior de Agricultura Luiz de Queiroz - ESALq, Piracicaba: Universidade de São Paulo.

BOUYCHOU, J.G. 1962. La saignée de l'Hévéa : manuel du planteur d'Hévéa. Paris: Revue Générale du Caoutchouc.

CATI, COORDENADORIA DE ASSISTÊNCIA TÉCNICA INTEGRAL. 1975. Projeto de assistência técnica à cultura da seringueira no estado de São Paulo. Campinas: Secretaria da Agricultura do Estado de São Paulo.

CIBOT, P. 1903. Le caoutchouc au Rio-Beni : notes sur la végétation et l'exploitation de l'Hevea en Bolivie. Paris: [publisher not identified].

COLLINS, James. 1872. Report on the Caoutchouc of Commerce, Being Information on the Plants Yielding It, Their Geographical Distribution, Climatic Conditions and the Possibility of Their Cultivation and Acclimatization in India. London: Allen.

COOK, O. F. 1928. "Beginnings of Rubber Culture: Special Characters of the Hevea Tree Determine Method of Tapping”. Journal of Heredity, 19(5): 204-15.

CROSS, Robert. 1876. "Report on the Investigation and Collecting of Plants and Seeds of the India-Rubber Trees of Para and Ceara and Balsam of Copaiba." Kew Gardens Archives - Miscellaneous Reports MR 117 India Office Caoutchouc Vol 1 1873-1904. London. Mimeo.

DEAN, Warren. 1987. Brazil and the struggle for rubber: a study in environmental history. Studies in environment and history. Cambridge, New York: Cambridge University Press.

DI DEUS, Eduardo. 2017. A dança das facas: trabalho e técnica em seringais paulistas. $360 \mathrm{f}$., il. $\mathrm{PhD}$ thesis in Social Anthropology - Universidade de Brasília, Brasília.

DOVE, Michael R. 2000. "The life-cycle of indigenous knowledge, and the case of natural rubber production”. In: R. F. Ellen, Peter Parkes, and Alan Bicker (eds.), Indigenous environmental knowledge and its transformations: critical anthropological perspectives. Studies in environmental anthropology, v. 5 . Amsterdam: Harwood Academic. pp. 213-251.

FAIRCHILD, David. 1928a. "Dr. Ridley of Singapore and the Beginnings of the Rubber Industry". Journal of Heredity, 19(5): 193-203.

. 1928b. "Early Days of Rubber Experiments: A Letter from Dr. Ridley Pictures Singapore of Thirty Years Ago". Journal of Heredity, 19(11): 485-86.

FERRET, Carole. 2012. "Vers une anthropologie de l'action: André-Georges Haudricourt et l'efficacité technique". L Homme, 202: 113-39. https://doi.org/10.400o/lhomme.23041.

GIBSON, James J. 1979. The Ecological Approach to Visual Perception. Boston: Houghton Mifflin.

GILLE, Bertrand. 1978. Histoire des techniques. Paris: Gallimard.

HARTIGAN, John. 2019. "Plants as Ethnographic Subjects". Anthropology Today, 35(2): 1-2. https://doi.org/10.1111/1467-8322.12491. 
HAUDRICOURT, André-Georges. 1962. "Domestication des animaux, culture des plantes et traitement d'autrui". L'Homme, 2(1): 40-50.

-1987. La technologie, science humaine : recherches d'histoire et d'ethnologie des techniques. Paris: Editions de la Maison des Sciences de l'Homme.

HOELZ, João Jacob. 1958. Cultura da Seringueira em São Paulo. São Paulo: Secretaria da Agricultura do Estado de São Paulo.

LA RUE, Carl Downey. 1926. The Hevea Rubber Tree in the Amazon Valley. Washington: U.S.

Department of Agriculture.

LABRE, Antônio Pereira. 1873. A Seringueira. Pará: Carlos Seidl \& C. Editores.

LABROY, O.; CAYLA, V. 1913. A Borracha no Brazil. Rio de Janeiro: Superintendência da Defesa da Borracha.

LEMONNIER, Pierre. 1992. Elements for an anthropology of technology. Ann Arbor, Mich: Museum of Anthropology, University of Michigan.

LEROI-GOURHAN, André. 1971. Évolution et techniques I - L'Homme et la Matière. Paris: Albin Michel. LOCK, Robert Heath. 1913. Rubber and Rubber Planting. Cambridge: Cambridge University Press.

NUGENT, Stephen. 2018. The Rise and Fall of the Amazon Rubber Industry: An Historical Anthropological Account. Abingdon, Oxon; New York, NY: Routledge.

PARKIN, J. 1910. "Tapping and Wound Response". The India-Rubber Journal: the organ of the rubber, guttapercha, asbestos and plastics industries, 39(1): 368B-368C; 428; 428A-428B.

RIDLEY, Henry Nicolas. 1910. "Historical Notes on the Rubber Industry". Agricultural Bulletin of the Straits and Federated Malay States, IX(6): 201-213.

. 1928. "History of the evolution of the cultivated rubber industry". Reprinted from "The Bulletin of the Rubber Growers' Association”, January.

. 1955 [1930]. "Evolution of the cultivated rubber industry". Reprinted from the Proceedings of the Instituition of the Rubber Industry, 2(4): 114-122. Cambridge: W. Heffer \& Sons LDT.

Royal Botanic Gardens - Ceylon. 1899. Circular. Series I, 12, 13, 14.

SAUTCHUK, Carlos Emanuel (org). 2017. Técnica e transformação: perspectivas antropológicas. Rio de Janeiro: ABA Publicações.

.; SAUTCHUK, João Miguel. 2014. "Enfrentando poetas, perseguindo peixes: sobre etnografias e engajamentos". Mana. Estudos de Antropologia Social, 20(3): 575-602. https://doi.org/10.159o/So10493132014000300006.

SIGAUT, François. 1975. "La technologie de l'agriculture. Terrain de rencontre entre agronomes et ethnologues". Études Rurales, 1(59): 103-11.

. 2011. "Le culte des ancêtres et la critique des héritages." In: Noël Barbe e Jean-François Bert (orgs.), Penser le concret: André Leroi-Gourhan, André-Georges Haudricourt, Charles Parain. Paris: Creaphis. pp. 103-108.

SILVA, Juliano Quarteroli et al. 2007. "Viabilidade econômica de diferentes sistemas de sangria em clones de seringueira”. Pesquisa Agropecuária Brasileira, 42(3):349-56.

https://doi.org/10.1590/S0100-204X2007000300007.

WACQÜANT, Loïc. 2002. Corpo e alma: notas etnográficas de um aprendiz de boxe. Rio de Janeiro: Relume-Dumará.

WEINSTEIN, Barbara. 1983. The Amazon rubber boom, 1850-1920. Stanford, California: Stanford University Press.

WICKHAM, Henry Alexander. 1876. "The Introduction of the Indian Rubber tree into India”. Kew Gardens Archives - Miscellaneous Reports MR 117 - India Office Caoutchouc Vol. 1, 1873-1904. London. Mimeo. 
. 1908. On the plantation, cultivation, and curing of Para Indian rubber. London: Kegan Paul, Trench, Trubner and Co Ltd.

WILLIS, J. C. 1906. "The Ceylon Rubber Exhibition 1906”. Kew Gardens Archives - Miscellaneous Reports 296 - Ceylon Rubber (1880-1908), folios 192-195. Mimeo.

WOLF, Howard; WOLF, Ralph Frank. 2009 [1936]. Rubber a Story of Glory and Greed. Shrewsbury: Smithers Rapra Technology.

\section{Acknowledgements}

The study on which this article is based was financed by the National Council for Scientific and Technological Development (CNPq) and the Coordination for the Improvement of Higher Education Personnel (CAPES), and conducted within the Post-graduate Programme in Social Anthropology at the University of Brasilia. I would especially like to thank to the rubber tappers who taught me about the rubber trees; to all the librarians who helped me with archival research; and to Carlos Sautchuk, who supervised the study.

Eduardo Di Deus

University of Brasília, Faculty of Education, Brasília/DF, Brazil

https://orcid.org/00oo-0001-9523-8844

Author's e-mail: eduardodideus@unb.br 